\title{
The Scope of the EU Charter and its Application by the Hungarian Courts
}

\author{
By Petra Jeney*
}

\begin{abstract}
This paper maps out the factors regarding the Charter's scope of application and then provides an overview of the subsequent interpretation afforded by the Court of Justice of the European Union (CJEU). The content and repercussions of the CJEU's interpretation of the field of application of the Charter in the Member States will also be discussed and, finally, the focus will be turned to how the Hungarian judiciary refers and applies the Charter. The analysis of the practice of the national courts will show that despite the CJEU's guidelines on situations when recourse to the Charter is required, Hungarian courts have applied a narrow reading of the Charter and have thereby insulated significant national measures that give effect to EU law from EU fundamental rights scrutiny.
\end{abstract}

Keywords: EU Charter, Court of Justice of the European Union, Hungarian judiciary, fundamental rights

\section{INTRODUCTION}

The EU Charter of Fundamental Rights is the primary written EU instrument for the protection of fundamental rights in situations falling within the ambit of EU law. However, since the EU Charter of Fundamental Rights (Charter) was proclaimed on 7 December $2000,{ }^{1}$ and its subsequent recognition of having equal value to the founding treaties by the Treaty of Lisbon, ${ }^{2}$ the precise scope of its application has been an issue of debate and, in some cases, concern. The Charter's applicability, especially in domestic context by the national courts, has been the source of uncertainty, despite the horizontal provisions found at the end of the Charter governing its scope and relation to national law and to that of the European Convention on Human Rights.

This paper maps out the factors regarding the Charter's scope of application and then provides an overview of the subsequent interpretation afforded by the Court of Justice of the European Union (CJEU). The content and repercussions of the CJEU's interpretation of the field of application of the Charter in the Member States will also be discussed and, finally, the focus will be turned to how the Hungarian judiciary refers and applies the Charter. The analysis of the practice of the national courts will show that despite the CJEU's guidelines on situations when recourse to the Charter is required, Hungarian courts have applied a narrow reading of the Charter and have thereby insulated significant national measures that give effect to EU law from EU fundamental rights scrutiny.

\section{DEFINING THE FIELD OF APPLICATION OF THE CHARTER WITH PRIOR CJEU CASE LAW}

Delimiting the applicability of the Charter is key for deciding its effects in situations when national law touches upon areas governed by EU law. Restricting the Charter to apply only to cases involving EU institutions, and making it marginally applicable in the context of

\footnotetext{
* Author's affiliation. E-mail: jeney@ajk.elte.hu

1 OJ C 364/01 18.12.2000.

2 Article 6(1) TEU provides that the Charter shall have the same legal value as the Treaties.
} 
national law that also serves as a vehicle of EU law, would eventually make the Charter an obsolete instrument. However, expanding the scope of the Charter by allowing it to apply to a broad range of EU law governed national situations, primarily related to the actions of the EU Member States, would lead to a much more vigorous EU fundamental rights scrutiny. Thus, the key issue in drawing the scope of the applicability of the Charter is how far the fundamental rights review of Member States' conduct will be taken if and when they operate under the auspices of EU law and much less about the issue of subjecting EU institutions to Charter review.

Among the final, horizontal clauses contained in Title VII of the Charter, Article 51 on the field of application stipulates that

' 1 . The provisions of this Charter are addressed to the institutions, bodies, offices and agencies of the Union with due regard for the principle of subsidiarity and to the Member States only when they are implementing Union law. They shall therefore respect the rights, observe the principles and promote the application thereof in accordance with their respective powers and respecting the limits of the powers of the Union as conferred on it in the Treaties.

2. The Charter does not extend the field of application of Union law beyond the powers of the Union or establish any new power or task for the Union, or modify powers and tasks as defined in the Treaties.'

This provision is not very different in substance from the original 2000 version $^{3}$ and contains further re-reassurances that the Charter shall not extend the scope of EU law or the competence of the EU. Concerns from the Member States regarding the ability of the Charter to extend the scope of EU law were and are closely linked to the scope of application of the Charter and how deeply the Charter is to penetrate into national law.

The first limb of paragraph 1 of Article 51 subjects the EU institutions, bodies, offices and agencies to the Charter. This identification of the primary aim of the adopting Charter did not trigger any particular comment in academic literature, during or after the drafting process. However, the text, elevated to the primary law level by the Treaty of Lisbon, kept the most ambiguous phrase in the second limb of paragraph 1 of Article 51, making the Charter applicable to the Member States 'only when they are implementing Union law'.

This formulation immediately begs two questions: what is meant by 'implementing Union law' and whether there could be a situation when the scope of the Charter and the scope of EU law would differ. The underlying issue is whether the Member States are only subject to the Charter when they are strictly giving effect to EU law, e.g., when transposing an EU directive or does the Charter have a broader range of application to all Member State measures falling under the scope of EU law. The first scenario would entail that the Charter would not be applicable to the Member States when they act within the field of EU law, but do not strictly implement EU law. This leads to the more general issue of whether the scope

${ }^{3}$ For the version proclaimed in Nice see: "1. The provisions of this Charter are addressed to the institutions and bodies of the Union with due regard for the principle of subsidiarity and to the Member States only when they are implementing Union law. They shall therefore respect the rights, observe the principles and promote the application thereof in accordance with their respective powers. 2. This Charter does not establish any new power or task for the Community or the Union, or modify powers and tasks defined by the Treaties."

4 This matter is made more complex since the German language version uses the term 'Durchführung' which translates as execution, whereas the French language version applies the term 'mettent en oeuvre' that translates as implementation. 
of the Charter is narrower than the scope of EU law where the applicability of the Charter is confined to the specific instances when Member States implement EU law.

The accounts ${ }^{5}$ of the debates surrounding the inception of the original Charter, from the first Convention responsible for drafting the Charter of Fundamental Rights ${ }^{6}$ and then subsequently on eve of the European Convention ${ }^{7}$ and then during the negotiations leading to the Treaty of Lisbon, all reveal that the drafters were very much aware of the gravity of the wording used. At the first Convention, the Presidium's drafting proposal that would have put Member States under the scope of the Charter 'when acting within the scope of Union law', was flatly rejected as being potentially too broad in scope. Consensus could only be reached by making recourse to wording that was used by the CJEU in a judgment rendered at the time of the drafting, where the formula of 'fundamental rights in the Community legal order are also binding on Member States when they implement Community rules ...' was rigorously defined. ${ }^{8}$

Academic writing quickly highlighted that the use of this particular formulation for subjecting Member States to respect fundamental rights as protected under the Charter was in fact more restrictive than the then-current case law of the CJEU. ${ }^{9}$ The Court, by then, had a long standing doctrine according to which Member States must respect EU law based fundamental rights not only when EU provisions directly providing for the protection of human rights are applied ${ }^{10}$ but also when Member States act to implement and apply EU law. This was construed in a rather broad manner in the seminal Wachauf case, ${ }^{11}$ which concerned the application of EU regulations on milk quotas by the Member State authorities as agents of EU law in the context of the shared administration of EU law. The Court found that in applying the said regulations, "those requirements [the protection of fundamental rights] are also binding on the Member States when they implement Community rules, [and therefore] the Member States must, as far as possible, apply those rules in accordance with those requirements'. ${ }^{12}$ It is clear from this wording that although the notion of implementation of Community law [EU law] is indeed used by the Court to oblige Member States to respect fundamental rights, it is done while referring to the application of EU law in general at the same time. Subsequent cases also support the observation that the Court has used the notion of implementing EU law, applying EU law and falling within the scope of EU law/Community law in an interchangeable fashion. ${ }^{13}$

These cases show that the Court never wished to confine the notion of 'the implementation of EU law' to a narrow meaning, referring strictly to transposition or

5 Report by Clemens Ladenburger, The Institutional Report, at the FIDE 2012 Conference on the 'Protection of Fundamental Rights Post-Lisbon - The Interaction of the Charter of Fundamental Rights, the European Convention and national Constitutions' see section 3.1.

6 The Cologne European Council (3-4 June 1999) entrusted the task of drafting the Charter to a Convention.

${ }^{7}$ European Convention on the Future of Europe convened by European Council which met in Laeken on 14 and 15 December 2001 which drew up the Treaty on the Constitution for Europe.

8 C-292/97 Karlsson [2000] ECR I-2737.

9 E.g. Pernice (2002) or more recently Peers, Hervey, Kenner, Ward (2014)1427-1449.

10 118/75 Rutili [1975] ECR 1219, 222/84 Johnston [1986] ECR 1651.

$115 / 88$ Wachauf [1989] ECR 2609.

12 C-929/97 Karlsson [200] ECR I-2737. paragraph 37.

13 C-442/00 Caballero v Fondo de Garantia Salarial (Fogusa) [2002] ECR I-11915 paragraphs 29-30. 
implementing an EU obligation to which a Member State is directly addressed. Given the diverse ways in which EU law is given effect in the national realm and that Member States, in principle, enjoy great freedom in choosing the means to that end, any restricted judicial interpretation of this notion probably would have proved highly unworkable in any case. Instead, the Court has construed this term to refer to any Member State action which gives effect to the enforcement of EU law and thus triggering the fundamental rights scrutiny exercised by the Court. It is not merely the construction of the scope of EU law giving rise to the fundamental rights protection that makes this all very forceful. This interpretation also made it possible for the CJEU to impose the obligation to respect fundamental rights on the Member States enforcing EU law even when the concrete EU measure had not specifically provided for the protection of fundamental rights. Thus, any and all EU measures were implicitly strengthened with fundamental rights as Member States' measures giving effect to them were now subject to a fundamental rights review. Admittedly, this was still the very beginning of EU fundamental rights scrutiny by the CJEU, done on a case by case basis and lacking any clear internal fundamental rights policy from the EU, furthermore the entire body of Community law was much less at the time. All this had changed by the time the Charter came into force some two decades later.

The Court has taken this broad interpretation further to the extent that the given measure is still liable to fundamental rights scrutiny even in situations where Member States decide to derogate from EU law. The leading case here is the ERT case, where the compatibility of the freedom of services and establishment with a Greek law granting exclusive rights to a radio and television company was at stake. In the case the Court made it clear that regardless of the fact that public policy exceptions from the free movement rules were invoked by Greece, this did not insulate the state measure from an appraisal in the context of the fundamental rights protection under EU law. ${ }^{14}$ Also, a Member State' restriction of EU fundamental freedoms was also considered as an instance that triggers the full respect of EU protected fundamental rights. This is exemplified by the well-known Schmidberger ${ }^{15}$ and Omega cases, ${ }^{16}$ where national measures for the protection of fundamental rights were accepted as public policy justifications for the limitation of EU free movement rights. It was only in the so-called 'wholly internal situations' where the CJEU refrained from reviewing Member States' action as they prima facie fell out of the scope of EU law. ${ }^{17}$

This ambiguity regarding the phrase used by the Article 51(1) of the Charter making it applicable to Member States 'only when implementing Union law' was not reduced by the Explanations relating to the Charter of Fundamental Rights, ${ }^{18}$ which was published with the Charter at the time of the adoption of the Lisbon Treaty. The Explanations draw on the Karlsson case ${ }^{19}$ as the leading authority on the meaning of "when implementing Union law'. As shown above, this notion is used by the Court in a broad sense, rather as a synonym

14 C-260/89 Elliniki Radiophonia Tileorassi (ERT) [1991] ECR I-2925.

15 C-112/00 Schmidberger [2003] ECR I-5649.

16 C-36/02, Omega, [2004] ECR I-9609.

17 C-299/95 Kremzow [1997] ECR I-2629.

18 OJ C 303, 14.12.2007, 17-35 in the light of the drafting adjustments made to the text of the Charter by that Convention (notably to Articles 51 and 52) and of further developments of Union law. Although the Explanations do not as such have the status of law, they are a valuable tool of interpretation intended to clarify the provisions of the Charter.

19 C-929/97 Karlsson [200] ECR I-2737. paragraph 37. 
to the notion of acting within the scope of EU law. The Explanations then go on and refer to two instances that the drafters possibly had in mind when coining the notion of 'implementing Union law', namely the Wachauf ${ }^{20}$ and the $E R T^{21}$ line of cases, where in implementing EU law Member States were obliged to respect EU fundamental rights. The European Convention's Presidium further refined the Explanations and added a reference to the Annibaldi case, ${ }^{22}$ which contained a more elaborate analysis on the sufficient links a situation needs to show with EU law to trigger EU fundamental rights protection.

Thus, while the text of the Charter uses the rather limited language of 'implementing EU law' in drawing the scope of the field of application of the Charter vis-á-vis the Member States, the Explanations did cite the current CJEU case law, thus allowing a much wider margin. However in this respect, the Explanations did not improve clarity but rather further demonstrated the gap between the Charter's formulation and the CJEU's practice on the exact scope of the field of application of fundamental rights.

There were important reasons for why the Explanations reiterated and took a broader view. The implication of drawing a narrow scope for the Charter, so that it applies to the Member States only when implementing EU law, is that there would be situations where Member States would be bound by the Charter and situations where, although still acting within the ambit of EU law, they would not be so bound. Craig points out that there is simply no normative argument for any such distinction in subjecting Member States to fundamental rights scrutiny. ${ }^{23}$ On the contrary, when Member States derogate from EU law or limit EU fundamental freedoms, they should be even more susceptible to a fundamental rights review of their actions based on EU law. Should any such distinction persist between the scrutiny over situations where EU Member States implement EU law and other instances where they merely operate under EU law further difficulties would arise. It could have been still possible that the CJEU would not recognise any such distinction, or at least would be reluctant to overrule its prior case law maintaining its own broader approach. There is nothing in the Treaty of Lisbon that would, even in an implied manner, support the above distinction of cases.

The CJEU maintained its broad view in defining situations when Member State measures falling under the scope of EU law during the numerous years between the proclamation and the final acceptance of the binding character of the Charter and despite the ongoing debate of the Charter's scope of application. To be sure a convincing string of cases support the view that fundamental rights scrutiny was applied to Member States not only when implementing EU law, more specifically transposing EU directives, ${ }^{24}$ but also when operating under the scope of EU law, and generally applying EU measures. In the

20 E.g. Pernice (2002) or more recently Peers, Hervey, Kenner, Ward (2014)1427-1449.

21 C-929/97 Karlsson [200] ECR I-2737. paragraph 37.

22 C-309/96 Annibaldi [1997] ECR I-7493.

23 Craig (2009) 212.

24 C-305/05 Ordre des bureaux francophone et germanophones [2007] ECR 5305 regarding the implementation of the Money Loundering Directive where the right to fair trial was raised, the 275/06 Promusicae [2008] ECR I-271 related to various EU directives on electronic commerce and electronic communication and right to property and privacy, 336/07 Kabel Deutschland [2008] ECR I-10889 where the implementation of the Universal Services Directive triggered the issues of freedom of expression, 421/2007 Damgaard [2009] ECR 2629, C-45/08 Spector Photo [2009] ECR I-12073 concerning the presumption of innocence in the context of the implementation of the EU Insider Dealing Directive. 
Österreichische Rundfunk and Lindqvist cases, for example, concerning the interpretation of Directive 95/46/EC on the protection of personal data, the Court found that authorities and courts of the Member States must not only interpret their national law in a manner consistent with the Directive, but that they need to ensure that no such interpretation is relied upon which would be in conflict as protected in the EU legal order. ${ }^{25}$

In the context of derogating from EU law and/or limiting EU fundamental freedoms, the Court has maintained the ERT and Schmiedberger line of cases. Prime examples of this are the Laval and Viking cases, where giving effect to EU freedom on services and establishment clashed with fundamental rights where the exercise of the former resulted in the justified limitation of the right to collective action. ${ }^{26}$ The Dynamic Medien case ${ }^{27}$ can also be cited where right of the child and protection of children was considered as legitimate justifications to limit the EU right free movement of goods.

In fact, the Court even expanded its already broad reading of cases interpreted as falling within the scope of EU law. In the Carpenter case, ${ }^{28}$ the situations falling within in the scope of EU law were stretched further by subjecting national immigration measures to fundamental rights scrutiny in a situation where the sole link to EU law was that the applicant's deportation would hinder their spouse's exercise of EU fundamental freedoms and be of a detriment of their right to family life. In the Mangold and later in the Kücükdeveci cases, the CJEU have taken the obligation to respect EU fundamental rights in applying EU law to situations between private parties. ${ }^{29}$ This move can also be read as giving more breadth to fundamental rights scrutiny not only by expanding the interpretation of the scope of EU law but also extrapolating it to horizontal situations.

What is clear is that on the eve of the Charter coming into force by being elevated to EU primary law, the issue of the exact scope of its application to the Member States was unclear. There was the Charter itself, with its use of rather restrictive language. However the Explanations, attached to the Charter, referred to the broader CJEU case law, though not to all of its aspects. Finally, there was the CJEU which was further expanding the terrain in which Member States were considered to be acting under the scope of EU law, thereby expanding the scope of national measures which were susceptible to fundamental rights review. It was against this rather unclear backdrop that the CJEU had to start applying and interpreting the Charter, now as proper EU law. This ambiguity to what degree will the Charter exactly penetrate into the Member States' legislative and administrative actions also explains why Member States found it crucial to supplement both the Charter and the Treaty on European Union with the disclaimer that the Charter shall not expand the competences of the EU.

25 C-465/00, C-138/01 and C-139/01 Österreichische Rundfunk [2003] ECR 2003 I-04989

C-101/01 Lindqvist [2003] ECR 12971.

26 C-438/05 Viking [2007] ECR I-10779.

27 C- 244/06 Dynamic Medien [2008] ECR 505.

28 C-60/00 Carpenter [2002] ECR 6279.

29 C-144/04 Mangold [2005] ECR I'9981 and later the C-555/07 Kücükdeveci [2010] ECR I-365. 


\section{THE ÅKERBERG FRANSSON CASE, AND ITS AFTERMATH}

The CJEU was understandably very cautious in making recourse to the Charter, given its non-binding status at the time, after its initial proclamation in December 2000. It was only six years later, that the Court turned directly to the Charter in a case where the European Parliament sought the annulment of the Family Reunification Directive, arguing that the instrument gives ground for Member States to restrict fundamental rights. ${ }^{30}$

Once there were no more open questions regarding the legal status of the Charter, the Court wasted little time in turning to its provisions to decide cases. The first series of these cases dealt with various situations falling under the scope of the Charter and calling for the interpretation of the rights contained therein. The Runevič-Vardyn case $^{31}$ was where the broad interpretation of Directive 2000/43/EC implementing the principle of equal treatment irrespective of racial or ethnic origin was justified based on Article 21 of the Charter, then the Bundesrepublik Deutschland $v B$ and $D$ case. ${ }^{32}$ The court invoked the Charter to interpret the so-called Qualification Directive in relation to the protection of refugees. The concept of EU citizenship was at stake in the McCarthy case, ${ }^{33}$ which is also re-affirmed by Article 45 of the Charter. In the Schecke case, ${ }^{34}$ the Court found provisions in various EU regulations invalid for requiring publication of information on the beneficiaries of agricultural aid the on the basis of the Charter.

Yet none of these cases provided an opportunity to precisely ascertain the precise scope of application of the Charter. It was the Akerberg Fransson case ${ }^{35}$ that finally brought the question of the interpretation of Article 51(1) of the Charter and the formulations of 'only when implementing EU law' and 'scope of EU law' directly before the Court.

It is worth considering the facts in detail as the case has a wide reaching impact regarding the question of the extent to which Member States' actions trigger fundamental rights protection afforded by the Charter when acting within the realm of EU law.

The reference, originated from a Swedish court, related to the prosecution of $\mathrm{Mr}$ Fransson, a fisherman, for VAT fraud and other tax offence. Mr Fransson argued that the charges should be dropped as the ne bis in idem principle, as reaffirmed in the Charter, was applicable for he had already been subject to tax penalties in an administrative procedure. Before going to the merits of the case, the Court needed to establish its jurisdiction and therefore ascertain whether the case did indeed fall under EU law and was not a wholly internal affair. The Swedish government, the European Commission and other four intervening governments ${ }^{36}$ vehemently argued that the case altogether fell outside the scope of EU law and the Charter could not, therefore, be invoked. Their position was that no implementation of EU law was at stake in the case since both the criminal and administrative proceedings arose from the application of national law. The Court, however, took a different position.

30 C-540/03 European Parliament v Council [2006] ECR I-5769.

31 C-391/09 Runevič -Vardyn and Wardyn [2011] ECR I-3787.

32 C-57/09 and C-101/09 Bundesrepublik Deutschland $v$ B and D [2010] ECR I-10979.

33 C-434/09 McCarthy [2011] ECR I-3375.

34 C-92/09 and C-93/09 Volker und Markus Schecke GbR and Heifert v Land Hessen [2010] ECR I-11063.

35 C-617/10 Akerberg Fransson ECLI:EU:C:2013:105. For scholarly writing on the cases see Fontanelli (2013) 315-334, Reestman, Besselink (2013) 169-175, Dougan (2015) 1201-1246.

36 The Czech Republic, Ireland, Denmark and the Netherlands. 
In its decision, the CEJU directly referred to Article 51(1) of the Charter arguing that the formulation 'only when implementing Union law' confirms the Court's previous case law related to the scope to which actions of the Member States must comply with the fundamental rights guaranteed by EU law. ${ }^{37}$ The decision then proceeded to repeat the wellknown tenets stating that the fundamental rights guarantee is afforded in all situations governed by European Union law, but not outside such situations' and thus the Court has no competence to review national legislation if that falls outside the remit of EU law. ${ }^{38}$ Turning to the actual formula used by Article 51(1) of the Charter, the Court recalled the Explanations, examined above, and with a bold move stated that according these and in line with Article 6(2) of the TEU and 52(7) of the Charter, 'the requirement to respect fundamental rights defined in the context of the Union is only binding on the Member States when they act in the scope of Union law'. ${ }^{39}$ The central dicta is that EU fundamental rights are applicable whenever national legislation falls within the scope of EU law and there cannot be situations covered by EU law where fundamental rights are not applicable. In other words, 'the applicability of European Union law entails applicability of the fundamental rights guaranteed by the Charter'. ${ }^{40}$

The implications of the Fransson ruling are far reaching in two distinctive ways. Firstly, the question of how to interpret Article 51(1) of the Charter was settled. In essence, prior case law is maintained and fundamental rights scrutiny is employed over national legislation if that comes under the scope of EU law. This is so regardless of whether the Member State measure stricto sensu implements, applies or enforces EU law, derogates or limits it, or in any way operates within the realm of EU law. But of course the Court makes all the disclaimers to the effect that this does not mean that the Charter would extend the scope of application of EU law. In fact, the opposite is true, namely that the protection afforded by fundamental rights, now also contained in the Charter, is simply triggered by a matter coming under the scope of the EU law. ${ }^{41}$ This leads to the second, and perhaps even more important implication of the ruling. According to the Court the factual scenario of the Fransson case falls under the scope of EU law, even though neither the application or implementation of EU law, nor a limitation or derogation from it, was at stake. The Court found a sufficient link to EU law even though the concerned Swedish national legislation on tax and VAT fraud was not adopted to specifically transpose Directive 2006/112 on the common system of value added tax. For the Court, it was sufficient that its application [was] designed to penalise an infringement of that directive and is therefore intended to implement the obligation imposed on the Member States by the Treaty to impose effective penalties for conduct prejudicial to the financial interests of the European Union'. Thus the link between the Fransson case's factual scenario and EU law was that the Swedish national legislation providing both criminal and administrative sanctions for tax fraud in the context of which the ne bis in idem principle was invoked as a general framework also served to carry out the rather general obligations stemming from EU law, "to take all legislative and administrative measures appropriate for ensuring collection of all the VAT due on its

37 C-617/10 A kerberg Frausson, Paragraph 18.

38 Paragraph 19 citing the well known case Case C-299/95 Kremzow [1997] ECR I-2629, paragraph 15; Case C-309/96 Annibaldi [2007] ECR I-7493, paragraph 13.

39 Paragraph 20.

40 Paragraph 21.

${ }^{41}$ Craig, de Burca (2015) 416. 
territory and for preventing evasion'. ${ }^{42}$ The mere fact that the criminal and administrative proceedings against Fransson occurred in the same regulatory regime designed to give effect to both national and EU tax law, including effective penalties, was sufficient for the Court to pull the entire matter under the scope of EU law.

Remarkably, this link was found to be insufficient for the Advocate General in the case, who argued that the national legislation merely 'secure[d] objectives laid down in Union law'43 and the measures taken by the state authorities in the concrete case were to punish the provision of false information by taxable persons to the tax authorities. This, according to the Advocate General, could not entail a responsibility for the EU to protect fundamental rights, the ne bis in idem principle specifically, as that would trigger the assertion that the general requirement in EU law to effectively collect VAT and prevent tax evasion entails the 'transfer of all the constitutional guarantees governing the exercise of the Member States' power to impose penalties, including the collection of VAT, from the Member States to the Union'. ${ }^{44}$ With this observation, the Advocate General goes to the heart of the matter; tax collection is undertaken by the Member States and the EU has no competence in this field, or with regards to the sanctioning of tax fraud and evasion. The general objective spelled out by the EU of wanting Member States to effectively collect VAT and penalize fraud is not sufficient to avail the fundamental rights regime in a case which is confined to the application of national tax law. However this approach was not followed by the Court.

Perhaps sensing the gap between handing down the dicta on Article 51(1) in the Fransson case and at the same time projecting EU fundamental rights protection to a factual scenario not evidently falling under the scope of EU, the Court subsequently used every single occasion to give hints to what factors qualify a case to be considered as falling under the scope of EU law. Immediately following the Fransson case, the Ymeraga, Siragusa and Hernandez cases all provided opportunities for the Court to refine its stance as to what is meant by the scope of EU law and when it considers a Member State to operate under EU law for the purposes of fundamental rights protection afforded by the Charter. This general approach, which sees the Court opening up a novel issue by making a sweeping statement and then use subsequent cases to fill the abstractly formulated dicta with substance, is well known. ${ }^{45}$

In the Ymeraga case ${ }^{46}$, the Court found the immigration matter falling outside the scope of EU law and went on, in detail, to explain the required criteria for a case to fall under the scope of EU law. In deciding on this matter, the Court noted that: 'it must be ascertained among other things whether the national legislation at issue is intended to implement a provision of European Union law, what the character of that legislation is, and

42 Paragraph 25 of the judgment citing 2, 250(1) and 273 of Council Directive 2006/112/EC of 28 November 2006 on the common system of value added tax (OJ 2006 L 347, 1.).

43 Opinion od Advocate General Cruz Villalón delivered on 12 June 2012 ECLI:EU:C:2012:340 paragraph 60.

${ }^{44}$ Opinion od Advocate General Cruz Villalón delivered on 12 June 2012 ECLI:EU:C:2012:340 paragraph 63.

45 Just to name the most well known: 4/73 Nold [1974] ECR 491 identify general principles of Community law, including the protection of fundamental rights, 22/70 Commission v Council [1971] ECR 263 on implied external competences, C-6 and 9/90 Frankovich and Bonifaci [1991] ECR 5357 in relation to state liability for violating EU law.

46 C-87/12 Ymeraga and Others ECLI:EU:C:2013:291. 
whether it pursues objectives other than those covered by European Union law, even if it is capable of indirectly affecting that law, and also whether there are specific rules of European Union law on the matter or capable of affecting it'. ${ }^{47}$

Applying this formula to the facts of the case resulted in that although the Luxembourgish law intended to implement EU law, the case itself was not governed by European Union law since the applicant had not availed his EU free movement rights and always lived in his state on nationality. Moreover the applicant was not considered a beneficiary either for the purposes of the Family Reunification Directive or for the Citizenship Directive. ${ }^{48}$ Hence the Court declined to consider the Luxembourg authorities' refusal to grant a right of residence to the applicant's family members from an EU fundamental rights perspective.

This case fits into the long line of cases related to EU free movement rights where the lack of exercising the free movement right results in the case being considered as covering a wholly internal situation and thus falling outside the scope of EU law. ${ }^{49}$ The use of the formula certainly distinguishes the Ymeraga case, especially seen as a specific effort to clarify and provide guidance for the propositions of the Fransson case. True, some elements of the test can be traced back to the Annibaldi ruling, where the lack of implementation of EU law; the pursuit of other objectives and the only indirect effect on the EU regulatory area led to the conclusion that the national measures fall outside the scope of EU law. ${ }^{50}$ But the test offered in Ymeraga is novel in that it is primarily used to ascertain whether a situation involving the implementation of European Union law also comes within the meaning of Article 51 of the Charter.

The exact same test was repeated in the Siragusa case, ${ }^{51}$ where a property owner carrying out alterations without permission was ordered by the Sicilian authorities to restore his property in a landscape conservation area to its former state. In its reference, the national court asked whether Article 17 of the Charter on the right to property precludes any such national measure. The CJEU, in declining its jurisdiction, carefully explained why such a case would not fall under EU law and hence would not come under the scope of the Charter. Specifically, the Court found that the aim of the national legislation to protect cultural heritage and landscape is an aspect of the protection of the environment, admittedly an objective shared by EU environmental law. According to the CJEU, more is needed for a case to come under the scope of EU law and qualify under Article 51(1) of the Charter as implementing EU law. At this point, however, the Court did not turn to the Ymeraga test immediately but continued in reasoning that a "certain degree of connection above and

47 C-87/12 Ymeraga and Others ECLI:EU:C:2013:291 paragraph 41.

48 Respectively Council Directive 2003/86/EC of 22 September 2003 on the right to family reunification (OJ 2003 L 251, 12) and Directive 2004/38/EC of the European Parliament and of the Council of 29 April 2004 on the right of citizens of the Union and their family members to move and reside freely within the territory of the Member States amending Regulation (EEC) No 1612/68 and repealing Directives 64/221/EEC, 68/360/EEC, 72/194/EEC, 73/148/EEC, 75/34/EEC, 75/35/EEC, 90/364/EEC, 90/365/EEC and 93/96/EEC (OJ 2004 L 158, 77 and corrigenda OJ 2004 L 229, 35, and OJ 2005 L 197, 34).

49 175/78 Saunders [1979], 35-36/82 Morson and Jhanjan [1982] ECR 3723. 64-65/96 Uecker [1997] ECR 3171.]

50 Case C-309/96 Annibaldi [1997] ECR I-7493, paragraphs 21-23.

51 C-206/13 Siragusa ECLI:EU:C:2014:126. 
beyond the matters covered being closely related or one of those matters having an indirect impact on the other' needs to exist. This is where the gap between the dicta of the Fransson case and the actual fact scenario of the same case is bridged by the Court. In the Siragusa case, the CJEU maintains every detail of its conclusions regarding Article 51(1) in the Fransson case, but refines the process for determining whether a specific case actually falls under EU law and thus triggers the Charter.

On this basis, the CJEU clarified that there are greater requirements for a case to fall under the scope of EU law than that the national measures share the same objective with that of the EU, have an indirect impact or generally fall into an area where the EU also has powers. One may dare ask whether the Fransson case itself would have passed this hurdle. In any case citing the formula from the Ymeraga case $^{52}$ and meticulously applying it to the facts of the Siragusa case led to the finding that EU law does not impose obligations to protect the landscape, akin to those laid down by Italian law. The Court found that EU legislation pursues different objectives than the national legislation even though EU law otherwise recognises the landscape as one of the factors to be taken into consideration in assessing the impact of a project on the environment. In addition the Court added that the fact that national legislation is capable of indirectly affecting EU law in itself does not constitute a sufficient connection between that legislation and EU law and finally the national provisions do not implement rules of EU law.

The Court went further, in a sort of obiter dicta and retrospectively explained the Fransson ruling. According to the Court, the primary objective of its ruling is to ensure the protection of fundamental rights in all areas of EU activity irrespectively of whether that is manifested through EU action or Member State implementation. Consequently, there is a need to ensure that the level of protection does not vary according to national laws as that would eventually undermine EU law. ${ }^{53}$ With this statement the circle is complete. In the Internationale Handelsgesellschaft case ${ }^{54}$ at the dawn of the EU fundamental rights regime, in the early seventies, the same reasoning was employed for inventing the general principles of EU law and identifying the protection fundamental rights as being part of that source of law. Today, when the written Charter of Fundamental Rights is at stake and its application to national measures 'implementing Union law' is to be determined, the same reason and justification is used but with different consequences.

Whereas at the time of Internationale Handelsgesellschaft, the mere proposition of employing an EU-based fundamental rights scrutiny over both the then Community and national implementing measures was revolutionary and was more driven to insulate EC measures from fundamental rights scrutiny stemming from national laws. It was for the preservation of the autonomy of EC law that a fundamental rights review having its source in EC law itself was necessary. Subjecting national measures implementing EC law under the same scrutiny was more of a secondary issue. Today, the legal scenario is much more complex, EU regulatory areas are vast and so are the subsequent national laws giving effect

52 See above 'implementation of EU law for the purposes of Article 51 of the Charter, some of the points to be determined are whether that legislation is intended to implement a provision of EU law; the nature of that legislation and whether it pursues objectives other than those covered by EU law, even if it is capable of indirectly affecting EU law; and also whether there are specific rules of EU law on the matter or capable of affecting it'.

53 Siragusa paragraphs 31 and 32.

54 11/70 Internationale Handelsgesellschaft [1970] ECR 1125, paragraph 3. 
to them. The autonomy of EU law has been already established, EU law based fundamental rights scrutiny is accepted as a baseline. The question here is rather the depth of this scrutiny touching upon domains reserved for the Member States. Equally subjecting the EU and its Member States to the same fundamental rights scrutiny is a well justified objective in ensuring that standards of protection remain the same and EU law based fundamental rights protection is afforded irrespective of the vehicle - national or EU - giving effect to the challenged measure. It can be reasoned that this is required to preserve the internal coherence of EU law. However, drawing the line between when Member States implement EU law and when they do not has become much more sensitive exercise then simply lamenting on the meaning of the formulation 'only when implementing EU law' formulation.

All of these arguments most recently resurfaced and were repeated in the Fernandez case. ${ }^{55}$ In this case, the CJEU rejected to subject the Spanish national legislation providing the employer a right to compensation from the state in respect of the remuneration paid to an employee during proceedings challenging that employee's dismissal beyond the 60th working day after the action challenging the dismissal was brought as falling outside the scope of EU law. ${ }^{56}$ The Court thus refused to review the Member State's measure under the Charter, employing the Fransson, Ymeraga and Siragusa line of cases and demonstrating that this is now considered as settled case law.

The Fransson case, complemented by the Ymeraga, Siragusa and Hernandez cases, provide an answer to the question of the scope of application of the Charter with respect to the Member States. The Fransson case confirmed that, despite the unfortunate language used in Article 51(1) of the Charter, the long standing case law of the CJEU stands firm and intact in pulling national measures under EU fundamental rights review should they fall under the scope of EU law. The Fransson case also confirmed that there are no scenarios when Member State operate under EU law but would not have an obligation to respect EU fundamental rights. Whereas the Fransson case is the big leap, its general language and also its rather weak factual scenario desperately called for further elaboration of the proposition it established. ${ }^{57}$ The Ymeraga case, relying on the tenets of the old Annibaldi ruling, provides a test as well, as to how to determine whether the national measures falls under the scope of EU law. The Siragusa case can be seen as the case which combined all these factors and the Court openly states that the Ymeraga test is needed to establish a connection between the said national measures and EU law in order to establish that the national measure falls under the scope of EU law. The Court also clearly explains the Fransson case's dicta that fundamental rights protection always follows national measures that come under the scope of EU law, now simply labelled as implementing EU law, without the qualifications thought to be present in the Charter. Admitting that the whole exercise in pulling any and all national measures implementing EU law under fundamental rights scrutiny is to ensure that no differences in protection levels occur due to different national standards and the unity and effectiveness of EU law is ensured that protection is afforded irrespectively whether it is the EU or its Member States that take action.

55 Case C-198/13 Hernandez ECLI:EU:C:2014:2055.

56 Directive 2008/94/EC of the European Parliament and of the Council of 22 October 2008 on the protection of employees in the event of the insolvency of their employer (OJ $2008 \mathrm{~L} \mathrm{283,36).}$

57 There is another aspect of the Fransson case related to Article 53 of the Charter on protection levels which read together with the Melloni and cases clarifies how and when Member States can uphold protection standards higher then afforded by the Charter. See C-399/11 Melloni [2013] ECR. 


\section{THE FRANSSON CASE LAW BEFORE THE HUNGARIAN JUDICIARY}

It is for the national courts, now equipped with the case law mapping out the exact scope of the applicability of the Charter in relation to legislation falling under the scope of EU law, to identify such instances and invoke the Charter accordingly. National courts are in the front line in applying and enforcing EU law. They are therefore the immediate instances where parties are able to challenge national laws that implement EU law and seek redress for alleged fundamental rights violations. In fact, national courts may not only be the most accessible and efficient, but also the only forum to provide remedies for the individuals challenging national measures that allegedly breach EU fundamental rights. This is why it is crucial for EU law as a whole that national courts fully comprehend the Fransson case law and are able to apply what it says about the applicability of the Charter vis-á-vis national measures giving effect to EU law.

The dicta of the Fransson case, the Ymargen case's test and their synthesis in the Siragusa case are all at the disposal of national courts for determining whether a given national measure falls under the scope of EU law, that triggering the protection ensured by the Charter. Unfortunately to date Hungarian national courts have not availed themselves to the guidance provided by the CJEU.

While the Fransson case itself has received little academic attention in Hungary, the whole issue of the scope of EU law and Article 51 of the Charter has recently been subject to intense litigation, with applicants invoking the applicability of the Charter. ${ }^{58}$ The first court case where this issue surfaced was a Constitutional Court order, where the court rightly concluded that the underlying factual scenario, relating to land use, fell outside the scope of the Charter as it did not involve the implementation of EU law from the part of the Member States. ${ }^{59}$ Similarly, in a case which concerned the sale of immovable property, the Miskolc court found that the underlying facts had no EU law aspect and was governed solely by national law, and hence did not fall under the scope of application of the Charter. ${ }^{60}$

A distinct group of cases where the Charter was cited by the applicants relates to the dismissal of civil servants, allegedly violating the Charter, after the Act on the status of civil servants was amended in 2010. In all these cases, the labour courts rightly considered the Charter and found it not to apply to the cases as amended Act did not fall under the scope of EU law. ${ }^{61}$

A more interesting group of cases that specifically dealt with Article 51 of the Charter and the scope of Charter applicability revolve around Act no XXXVIII of $2014^{62}$ on consumer credit. The Act renders all consumer credit contracts retroactively unfair as the

58 Case available at the Bírósági Határozatok Gyüjteménye at <http://birosag.hu/ugyfelkapcsolatiportal/anonim-hatarozatok-tara $>$ were analysed for the purposes of this paper. Accessed 7 February 2016.

$593140 / 2013$ of $02 / 07 / 2013$. The very first judgment mentioning the Charta since it was invoked by the plaintiff being Pf.V.20.345/2010/20.

60 13.G.40.123/2013/14. See also Pf.I.20.131/2014/5., 17.P.20.050/2013/47, 25.P.21.867/2011/15, 25.P. 22.432/2008/61 Gf.II.30.106/2015/7., Pf.II.20.712/2013/9., Gf. III. 30.135/2014/5.

61 2.Mf.20.981/2014/4., Mf.634735/2012/4, Mf.637399/2012/5, Mf.634070/2012/549. But see to the contrary Mf.638866/2012/3 where the court found that the dismissal was unlawful and also violated the Charter, although the underlying facts did not come under the scope of EU law.

${ }^{62}$ In itself a curious piece of legislation bearing the title of Act no XXXVIII of 2014 on settling certain issues arising from the authoritative judgment of the Kúria on consumer credit contracts of financial institutions (Act on consumer credit). 
general terms and conditions of these contracts allowed for the possibility of a unilateral modification of the contract with respect to interest rates, fees or charges. The Act triggered a series of litigation as foreign currency based consumer contracts, which by definition allowed for the raising of credit fees to follow exchange rates fluctuation, were now considered unfair with reference to Directive 93/13 on unfair terms in consumer contracts. ${ }^{63}$ Applicants challenged the underlying legislation on numerous grounds, among others as violating the Articles 47 (right to fair trial), 16 (freedom to conduct business) and 17 (right to property) of the Charter, which were claimed to be applicable to these cases through Article 51. Along the same lines, the applicants questioned the compatibility of the Act on consumer credit with EU law, including the Charter, and sought a request for a preliminary ruling.

The Metropolitan Court and the Supreme Court (Kúria), in their respective decisions but using similar lines of argument, denied the applicability of the Charter. One judgment, for example, considered invoking the Charter in the context deciding whether there is a need to refer the matter before the CJEU solely. ${ }^{64}$ It arrived at the striking conclusion that since the applicants had not sought for the interpretation of EU law (but challenged the compatibility of domestic law with rights protected under the Charter and principles of EU law), there was by definition no room for the court to make a preliminary reference. Besides this complete misunderstanding of the material scope of the preliminary reference, the court did not even consider the application of the Charter to the substantive part of the case i.e. by considering domestic law as implementing EU law under the auspices of the EU Charter. Some of the judgments in this line of cases did not consider the Charter at all even though it was raised by the applicants. One judgment stated that the underlying issues do not concern EU law and hence completely disregarded not only the Charter but Directive 93/13. ${ }^{65}$ In another judgment, the court stated that the Charter was not applicable since the underlying Act was not meant to implement EU law. Amusingly, the court went on to add since the State was the respondent in the civil suit case and not exercising its public power that Directive 93/13. ${ }^{66}$ Another judgment, ${ }^{67}$ based on the same factual scenario, at least considered the applicability of the Charter to the merits of the case but found that it was not applicable since the Act on consumer credit is not an implementation measure as it was not intended to transpose Directive 93/13. It added that even if this was not so, the interpretation of the Charter would still not be relevant as it was not related to the issue of determining whether the contractual provision was unfair.

63 OJ L 095 21/04/1993.

64 32.G.43.296/2014/13., 32.G.43.297/2014/18., 25.G.43.377/2014/8., 30.G.43.498/2014/6, 30.G.44.142/2014/5, 8.G.43.411/2014/17, 32.G.40.113/2015/9. and 4.G.40.147/2015/7. Reaching the same conclusion through a very brief reasoning 36.G.43.409/2014/6.

65 14.G.43589/2014/8., where the applicant did raise the Charter but the Court found that the issues do not concern EU law but national law only, hence did not even consider the Charter. See also 57.G. 43.425/2014/8., 4.G.44559/2014/4., G.40240/2015/7.

66 1.G.43.295/2014/8.

67 5.G.43.386/2014/7. See also 25.G.43.288/2014/9., 25.G.43.377/2014/8., 5.G.43.469/2014/6., 19.G. 43.382/2014/9., 35.G.43.833/2014/10., 36.G.43.409/2014/6., 19.G.43.383/2014/9., 3.G.43.467/ 2014/8., 5.G.43.587/2014/6. 
One of the more thoroughly reasoned judgment ${ }^{68}$ repeats the arguments found in the above decisions in a much more comprehensible manner. Whereas the previous court decisions simply stated that the Act on consumer credit was not an implementing measure, here the reasoning goes further and says that the Act merely synthetizes the existing jurisprudence related to the grounds upon which unfairness of a consumer contract may be established. As the Act on consumer credit did not create new grounds of unfairness that could result in nullity, it cannot be regarded as intervening into the contractual relationship of the parties. The reasoning concluded that should the Charter be found applicable no question of interpretation arises, since the unfair terms would in any case not be reviewed under the Charter. This judgment gets the closest to considering the key underlying issue regarding the determination of the scope of application of EU law in relation to Article 51's notion of 'when [Member States are] implementing EU law'.

Directive 93/13 only vaguely defines what is meant by an unfair term in a consumer contract, providing an indicative and non-exhaustive list of the terms which may be regarded as unfair in its Annex. It therefore leaves the issue of enumerating unfair terms more specifically for the Member States, which in practice means for national courts. Hence EU law, while securing minimum harmonisation of the unfair terms of consumer contracts (definition of consumer contract and consequences of an unfair term), leaves a wide margin for the Member States to define the notion of what is considered unfair. The issue, of course, is whether Member States, in operating facilitating this wide margin, remain in the domain of their national law or have come under the auspices of EU law, the latter of which would trigger the applicability of the Charter.

In light of the Fransson case law, ${ }^{69}$ to which some of the above judgments actually refer, ${ }^{70}$ the mere fact that the Act on consumer credit was not adopted to transpose a Directive does not insulate it from the scope of application of EU law triggering the Charter. The Act on consumer credit was especially designed to consolidate the issue of unfair terms of consumer credit contracts, thus in effect it facilitated the application of Directive 93/13 in this specific field. It should therefore be regarded as constituting the implementation of Directive and as such would fall under the scope of EU law for the purposes of Article 51 of the Charter. ${ }^{71}$

The above judgments show a very narrow reading of Article 51 of the Charter by Hungarian courts, limiting its applicability to only those situations where EU law is specifically transposed by a given national measure. This interpretation materially deprives private persons of the protection afforded by the Charter in situations when Member States apply EU law, give effect to EU law through national legislation, provide remedy or when simply ensure a procedure for the application of EU law. Everything that the Fransson, the Ymeraga and the Sirgausa cases have established regarding Charter applicability is ignored, giving way to a very restricted reading of the Charter. The consequence of this is to insulate

68 19.G.40.282/2015/7. See also 35.G.40.319/2015/8. examplifying an elaborate discussion of the applicability of the Charter.

69 C-617/10 ECLI:EU:C:2013:105.

70 25.G.43.288/2014/9.; 25.G.40.109/2015/5.; 25.G.43.377/2014/8.

71 See paragraphs $27-28$ of the judgment. 
national measures giving effect to EU law from EU fundamental rights scrutiny. ${ }^{72}$ Should this practice be maintained, restricting the effect of the Charter in the Hungarian domestic context by systematically failing to apply the Charter to national measures coming under the scope of EU law may also add up as a breach of treaty obligations and incur state liability under EU law. ${ }^{73}$

\section{CONCLUSION}

After a decade of limbo, the EU Charter of the Fundamental Rights is now the full-fledged EU primary law instrument for the protection of fundamental rights. As it was shown above one of the pivotal questions relating to the scope of the Charter was how to delimit its applicability. In particular, the key issue was whether to confine its applicability to cases involving EU institutions and making it only marginally applicable in the context of national laws that also serve as vehicles of EU law or to allow the Charter to govern a broad range of situations where national laws intersect with areas governed EU law.

It was demonstrated that the drafters of the Charter were very much aware of this question and perfectly comprehended that should the Charter be afforded with greater breadth, this would in effect entail scrutinizing a much wider range of Member States' measures, touching upon domains thought to be left to national competence. The gravity of this issue led to a compromise that the relevant Charter article uses a restrictive language, confining the applicability of the instrument in relation to the Member States 'only when implementing Union law'. However, by the time the issue of how broad a scope to give the Charter surfaced, the CJEU has already developed its own interpretation of what situations trigger EU fundamental rights scrutiny. This case law is noted by the Explanations attached to the Charter, which serves as a guide in interpreting and applying the Charter in the context of national measures.

Once the Charter came into full effect, it was for the Court to bring clarity to the issue of applicability and it was just a matter of time for the relevant case law to develop. It was the Akerberg Fransson case when the Court specifically addressed how to interpret the formulation of 'only when implementing Union law' and found that the Charter is indeed applicable whenever national legislation falls within the scope of EU law. The Court thus projected its pre-Charter case law on defining the scope of EU human rights review vis-ávis national measures and reinforced that the scope of the Charter shall be read accordingly. This meant that whenever national law operates under the scope of EU law, EU fundamental rights scrutiny would follow. One of the main repercussions of the Fransson case is that there would be no such scenarios where a Member States operated under EU law without

72 There is another aspect of the Fransson case which goes beyond the scope of this paper is related to paragraph (3) Article 52 of the Charter pitching the standard of protection provided by the Charter to that of guaranteed by the European Convention of Human Rights. The considerations made by the CJEU in this regard were rightly followed in two subsequent Hungarian court judgments. See Kfv.III.37.666/2012/27. and Kfv.III.37.690/2013/29. This latter judgment is particualry interesting as recourse to the Charter being the vehicle of the ECHR allowed the national court to enforce higher standrads of protection in competition law cases despite a contrary provision of the Code on Civil Procedure.

73 C-224/01 Köbler [2003] I-10239. 
the obligation to respect EU fundamental rights. Subsequent cases gave guidance in deciding whether a given case falls under the scope of EU law for the purposes of fundamental rights review. In the Ymeraga case, the Court added that for a national measure to come under the scope of EU law it must be ascertained whether the measure has intended to implement EU law; what objectives the measure pursues; what is the character of the national legislation and whether there is specific EU legislation on the matter. For a national measure to come under the scope of EU law, more is required than sharing the same objective with that of the EU, having an indirect impact or generally falling into an area where the EU also has powers. In the Siragusa case, the CJEU further noted that in general a certain degree of connection is needed between a national measure and EU law beyond that the matters covered are simply closely related or have an indirect impact.

In light of the key role of national courts in giving effect to EU law, and thereby also to the Charter, it is primarily for the national courts to correctly identify when national measures operate under the scope of EU law and thus trigger the application of the Charter. The interpretation afforded by the CJEU in the Fransson, Ymeraga and Siragusa cases provide clear guidance as to the factors to consider in deciding whether the underlying case falls under the scope of EU law. They also send a very strong message to the effect that in principle Member States are bound to respect EU fundamental rights whenever they operate on the terrain of EU law.

In view of this heightened responsibility of national courts in making the Charter truly effective an overview of how Hungarian national courts have used the guidance in the Fransson, Ymeraga and Siragusa cases was presented. The analyses of the cases where courts considered the applicability of the Charter shows a very narrow reading of its scope. The examined judgments all revert to a very limited reading of the Charter, irrespective of the CJEU's interpretation, and confine the Charter's applicability to situations when a Member State specifically transposes EU law. This restricted interpretation materially deprives private persons from benefiting from EU fundamental rights protection in all other situations where the said national measure does not specifically transpose an EU measure, but comes under the scope of EU law in some other way. The consequence of this narrow reading of the Charter is to insulate a significant volume of national measures that give effect to EU law from EU fundamental rights scrutiny. This is the direct opposite outcome from the interpretation the CJEU afforded to the applicability of the Charter as mapped out in the Fransson, Ymeraga and Siragusa cases.

\section{LITERATURE}

Craig, P., de Burca, G., EU Law (6 ${ }^{\text {th }}$ edn, Oxford University Press 2015).

Craig, P., The Lisbon Treaty, Law, Politics and Treaty Reform (Oxford University Press 2009).

Dougan, M., 'Judicial Review of the Member State Action under the General Principles and the Charter defining the "Scope of Union Law" (2015) 52 Common Market Law Review 1201-1246.

Fontanelli, F., 'Hic Sunt Nationes: The Elusive Limits of the EU Charter and the German Constitutional Watchdog: Court of Justice of the European Union: Judgment of 26 February 2013, Case C-617/10 Akklagaren v. Hans Akerberg Fransson' (2013) 9 European Constitutional Law Review 315-334.

Pernice, I., 'The Charter of Fundamental Rights in the Constitutions of the European Union' (WHI Paper 2002).

Reestman, J. H., Besselink, L., 'After Akerberg Fransson and Melloni' (2013) 9 European Constitutional Law Review 169-175.

Peers, S., Hervey, T., Kenner, J., Ward, A. (eds) The EU Charter of Fundamental Rights: A Commentary (Hart Publishing 2014) 1427-1449. 